\title{
Trade Union Responses to Transnational Labour Mobility in the Finnish-Estonian Context
}

\section{Rolle Alho}

PhD candidate, Faculty of Social Sciences, University of Turku, Finland ${ }^{1}$

\begin{abstract}
This article examines trade union strategies in relation to labor migration in Estonia and Finland, drawing on face-to-face interviews with trade unionists and official union statements. The study considers the national trade union strategies located in two separate but interconnected localities that represent different approaches to market economy. Previous research suggests that the national industrial relations system is a key factor in explaining unions' labor migration strategies. Unions operating in liberal market economies are claimed to be more open toward immigration and more inclusive toward immigrants than unions in coordinated markets. This study analyzes the extent to which this theory holds in the context of Estonia and Finland-Finland representing a coordinated market economy and Estonia a liberal market economy. Furthermore, the analysis examines how the emergence of a translocal labor market, resulting from the geographical vicinity and linguistic affinity between Finland and Estonia as well as from free mobility within the EU, is reflected in trade union approaches to labor migration. The study finds that Finnish trade union strategies influence labor mobility, whereas Estonian trade unions remain bystanders in the issue.
\end{abstract}

\section{KEY WORDS}

Labor markets / migrant workers / strategy / trade unions / translocal linkages / transnational labor mobility / varieties of capitalism

\section{Introduction}

rade unions always operate in a specific institutional context, which is related to the
nation state (e.g., Penninx and Roosblad 2000). Consequently, this article on trade
union strategies in relation to transnational labor mobility in Finland and Estonia
considers the particular institutional features of the two national contexts as enabling
and constraining structures within which trade unions act.
According to "conventional wisdom," trade unions attempt to restrict immigration
in order to keep the supply of labor low, whereas employer organizations strive for
liberal labor migration policies as a means to guarantee a suitable inflow of labor force
into the labor markets. Recent research has, however, provided a more nuanced picture
regarding trade union strategies. According to this strand of literature, trade unions
have in many cases diverted from restrictive strategies during the last two decades (Haus
2002; Holgate 2005; Menz 2011, pp. 263-264; Watts 2002). In practice, this has meant
agreeing to-and in some cases promoting-liberalization of immigration policies
(Briggs 2001; Haus 2002; Krings 2009; Menz 2011; Milkman 2010; Watts 2002). Many

${ }^{1}$ E-mail: rolle.alho@helsinki.fi 
trade unions have also allocated increasing resources to organizing migrants and ethnic minorities, who they view as a source of organizational strength (Menz 2011, pp. 263-264; Milkman 2010). The shift has also been explained by unions increasingly questioning the effectiveness of restrictive immigration policies, but also as a consequence of the internationalization of human rights concerns (Briggs 2001; Haus 2002; Watts 2002).

The selected approach in this article extends the work of David Soskice and Peter Hall (2001) on varieties of capitalism (VoC) approach with Walter Korpi's (1998) theory regarding institutionalization of power resources concerning the distribution of power in capitalist societies. The VoC approach distinguishes two ideal types of categories of political economy: liberal market economies (LMEs) and coordinated market economies (CMEs). Of the two countries under scrutiny, Estonia represents an LME and Finland a CME. In LMEs, the coordination logic of market relations tends to be more dependent on demand and supply conditions in competitive markets, whereas in CMEs, the markets tend to be more institutionally regulated (Soskice and Hall 2001, pp. 1-68). This leaves more influence for trade unions and, e.g., employer organizations in CMEs compared with the situation in LMEs. This article will show that this distinction is related also to trade unions' strategies as regards transnational labor mobility.

The extent to which the interplay between the labor market partners is institutionalized, as well as the extent to which the state is a party in that interaction, varies remarkably between countries, constraining and enabling the avenues available for trade union action. Trade unions gain access to political actors and bargain with employers through practices of institutionalized coordination of markets. Power resources related to the coordination of markets are essential as regards the bargaining power that trade unions can mobilize in relation to employers and the state (Korpi 1998, p. 54). In the absence of bargaining power and access to lobbying, trade unions have to take recourse in alternative strategies. However, capitalist markets function both at the national and transnational level. Analysis of the context for trade union action needs to take into consideration not only such transnational market dynamics but also the related translocal linkages resulting, for instance, from the rise of translocal recruitment patterns. Also, transnational institutional forces reshape national political economies and influence the national power resources that are wielded by trade unions. In this article, the term translocal will be applied as it often is in migration and cultural studies, i.e., in order to grasp the spatial cross-border local-to-local spatial dynamics, instead of highlighting the global/local dimension of globalization (e.g., Brickel \& Datta 2011, p. 10; Ma 2002). Schein and Oakes $(2006$, p. 20) argue that translocality “deliberately confuses the boundaries of the local in an effort to capture the increasingly complicated nature of spatial processes and identities as place-based rather than exclusively mobile, uprooted or 'traveling'". A concrete example of a translocal phenomenon is the emergence of a translocal labor market between the capital areas of Helsinki and Tallinn. The term transnational refers to state border-cutting practices by nonstate actors such as enterprises or individual workers (e.g., Sklair 2001).

There are, however, national differences in the coordinating power resources to which trade unions have access. These become visible in trade union responses to migration and migrants. Trade union influence on migration policy is mediated through institutionalized labor market relations. Furthermore, historical legacies of migration (Penninx \& Roosblad 2000, p. 184-186; Roosblad 2002; Roosblad \& Marino 2008) as 
well as histories of translocal linkages constitute vital conditions structuring trade union strategies aimed at influencing a specific labor market. Here, too, there is a linkage to power resources: Menz (2011, p. 26) argues that "past choices of migration regulation in Europe inform current policy design in terms of options, choices, debates, and perceptions of problems and possible regulatory solutions." Reflecting the assumption of such path dependency in migration and labor policies, it can be assumed that in countries like Finland, policy design creates specific windows of opportunity for trade unions, but that in countries like Estonia, where coordinating mechanisms are largely absent, trade unions lack such possibilities.

Analysis of trade union responses to migration is of societal importance: the viability of trade union strategies around questions of mobility has a bearing on the unions' own future. Furthermore, the strategies potentially also impact the situation of the individual migrant worker, and have implications for the labor market at large.

This article argues that even in the era of emerging transnational labor markets, the national industrial relations system shapes the strategies of trade unions in Estonia and Finland as regards transnational labor mobility. The main research question is: how do trade unions in Finland and Estonia perceive and react to the phenomenon of transnational labor mobility from Estonia to Finland? The study also addresses how these trade unions perceive and react to transnational labor mobility on a general level, i.e., not just labor mobility from Estonia to Finland. In addition, the article discusses the extent to which previous theory on trade union strategies regarding labor migration holds in the context of Estonia and Finland.

In this article, trade unions are understood as rational actors whose strategies have certain goals. The term strategy refers to trade unions' goal-oriented and relatively wellestablished ways of operating. The analyzed cases are the Finnish Construction Trade Union (in Finnish Rakennuslitto, FCTU) and the Estonian trade union movement. ${ }^{1}$ The analysis recognizes that trade union strategies are nowadays influenced by both translocal linkages and transnational institutional aspects, made possible by, for instance, free mobility in the EU. Estonia and Finland are neighboring countries whose translocal linkages are shaped by close contact since the fall of the Soviet Union, linguistic affinity, easy and relatively cheap access, and a partially shared transnational institutional framework, as both countries belong to the European Union, Schengen Area, and the Eurozone (i.e., have the same currency). Even before the fall of the Soviet Union visibility of Finnish television in Estonia provided an alternative to Soviet propaganda for many Estonians (e.g., Zetterberg 2007, p. 713). In sum, this study considers Finnish and Estonian trade union strategies located in separate but linked localities that are examples of different approaches to market economies with dissimilar opportunities for trade unionism.

The article is organized as follows. The first section introduces the analytical approach to trade union strategy vis-à-vis migration and migrants. The second section outlines the research design that underlines the need to consider national, transnational, and translocal dynamics in the formation of trade union strategies and presents the contrastive case study. A presentation of the empirical findings follows, with focus on how differences in market economies are reflected in trade union power resources and strategies. The last section concludes by summarizing, explaining and discussing the key findings, arguing that even in the era of transnationalization of labor markets, national contexts continue to play a role, as the institutional contexts may or may not create windows of opportunity for trade union action. 


\section{Analyzing trade union strategies in an institutional context: the coordination of market economies and trade union power resources}

Migration requires that unions assess their boundaries regarding solidarity, in terms of how ethnic and linguistic diversity and the issue of nonnationals are encompassed into a union's existing organization, often historically represented by native, white, male workers (e.g., Mulinari \& Neergaard 2004; Ristikari 2013). For unions, the inclusion of migrants has both an ideological and a strategic component (Penninx \& Roosblad 2000, p. 8). From the perspective of the individual migrant worker, trade union membership can ideally offer economic and social protection and give access to political and other forms of participation (Vranken 1990, pp. 47-73).

Recent research emphasizes that trade union strategies regarding labor migration are partly determined by the national labor market model, although trade unions have choice regarding their implementation (Bengtsson 2013; Hardy et al. 2012; Haus 2002; Krings 2009; Lillie \& Greer 2007; Marino 2012; Penninx \& Roosblad 2000; Watts 2002; Wrench 2004). A number of studies apply the VoC approach in analyzing trade union strategies toward labor mobility and migrant workers in different national contexts (Johansson 2012; Krings 2009; Menz 2011). Although much of the earlier research employing the VoC approach has focused on the strategies of firms, the analytical approach in itself takes into account the macro-characteristics of national political economies and the role of key institutional factors such as labor relations (Hancké et al. 2008, p. 5). Recent research (Bechter et al. 2012) has criticized the VoC approach of methodological nationalism for overemphasizing the differences of various national industrial relations while underestimating the variety of sectoral industrial relations within countries. Despite this valid critique, I am utilizing VoC in this article because Bechter et al. (2012) find that of all 27 EU countries, Finland exhibits the most homogenous industrial relations (least variance in the coordination logic within sectors). Estonia for its part is one of the EU's most heterogeneous countries in this respect (ibid.). Hence, Finland and Estonia, unlike many other "mixed model" countries, fit well into the ideal type of models offered by the VoC, Finland being a CME and Estonia an LME.

A key insight arising from studies of trade union strategies from the $\mathrm{VoC}$ perspective is the uncovering of systematic differences in trade union strategies between countries representing different approaches to capitalism. According to Torben Krings' (2009) fourcountry VoC-inspired analysis of unions in LME countries, Britain and Ireland appear to be "more open" toward migrant labor than unions in CMEs, Germany and Austria. Unions in the United Kingdom and Ireland have been inclined to assess that labor standards are best protected by enforcement of rights, rather than restrictions on transnational workforce mobility. They have allocated increasing resources to the mobilization of migrants into unions, seeing them as a potential power resource for regaining lost membership and societal influence. Unions in Germany and Austria, which have a stronger institutional connection to the national industrial relations system, have been inclined toward supporting more restrictive immigration policies and have placed less emphasis on reaching out to migrant workers, as these unions do not have the same incentives to reach out to migrant workers owing to their relatively strong institutional position (ibid.). ${ }^{2}$

The present study builds on these insights about how different institutional contexts give rise to systematic differences in trade union strategies. However, I develop 
the VoC approach with a more systematic consideration of trade union power resources and argue that the institutional interplay of labor market partners is a key feature of the coordination of markets (see Korpi 1998). Finland and Estonia offer almost textbook cases of the two different approaches to market economies: CME Finland is characterized by comparatively influential trade unions and employer organizations that have high coverage as regards collective agreements, whereas this is not the case in LME Estonia. Trade union density is also higher in CMEs than in LMEs (Soskice \& Hall 2001, p. 59). Finland confirms this, as $95 \%$ of the workforce is covered by collective agreements, and nonunionized workers are protected by collective agreements on the erga omnes principle (e.g., Böckerman \& Uusitalo 2006, p. 284). In contrast, the share of workers covered by sectoral collective agreements is only $25 \%$ in Estonia (2005 Working Life Barometer Survey Estonia), and Estonia has national collective agreements in only a few industry sectors (Sippola 2009). Trade union density is between 62 and 67\% in Finland (Ahtiainen 2009) and only $8 \%$ in Estonia (OECD Statextracts 2012). This high density in Finland is partly explained by the long-term state recognition of the so-called Ghent system, where employees belonging to an unemployment fund administered by a union receive higher unemployment benefit than nonmembers (Böckerman \& Uusitalo 2006). The Ghent system increases incentives to join a trade union (ibid.; Voxted \& Lind 2012), and high density is in itself an important trade union power resource (e.g., Scheuer 2011). However, private unemployment funds have been allowed in Finland since the early 1990s, which has led to a decrease in density (Böckerman \& Uusitalo 2006). Finnish unions have traditionally gained access to government decision-making via "blue collar" trade unions having links to the left wing political parties (Bergholm 2003). Such political clout is another vital power resource for trade unions. The Finnish labor market system has during the last decades been characterized by a relatively high degree of trust and institutionalized cooperation between the labor market parties and the state (ibid.). Trust and institutionalized cooperation constitute immaterial power resources, in that they increase the political clout of trade unions and give them windows of opportunity for societal influence.

Estonia has followed a market liberal/neoliberal model of development with little role for trade unionism (Feldmann 2008; Mrozowicki 2013 et al.; Sippola 2009). The vast difference in the position of trade unions in Finland and Estonia can be illustrated by the FCTU having more members $(89,000)$ than the entire Estonian trade union movement $(46,000)$ (Source: FCTU and Estonian trade union confederations). In addition, the countries have very different migration histories, as will be shown later. The rise of a translocal labor market linking Helsinki and Tallinn is an important aspect of the cases explored here.

\section{Analysis of trade union strategies}

In the research literature, trade unions are seen to be facing a series of choices, or “dilemmas" regarding immigration (Penninx \& Roosblad 2000). Here we divide trade union strategies as regards migration and migrants into two categories:

1. Mobilizing strategies.

2. Strategies along the governmental dimension. 
Studies that emphasize mobilization strategies regarding migrants/ethnic minorities (e.g., Milkman 2010; Nash 2001; Sherman \& Voss 2000) fall under the so-called trade union revitalization/renewal literature that focuses on unions' proactive efforts to regain their lost societal impact/power resources by, for instance, targeting "new" potential—often underrepresented-demographic groups such as migrants. This school pays attention to situations where trade unions operate as social movements rather than administrative agents. This type of unionism is sometimes called "social movement unionism" or "community unionism," owing to its emphasis on building new contacts and links outside "traditional" labor relations and beyond the workplace. Immigrant mobilization strategies aimed at trade union "renewal" also include "the recruitment of new staff that, in terms of orientation and previous work experience, can lend weight to the change process" (James \& Karmowska 2012, p. 204). ${ }^{3}$

Strategies of the second category, i.e., strategies along the governmental dimension, include administrative efforts at all levels of government where unions actively draft or promote legislation regarding the regulation of the industrial relations framework (e.g., Behrens et al. 2006, pp. 11-29). These strategies can be inclusive or exclusive, or have dimensions of both. ${ }^{4}$

\section{A contrastive case study design of two translocally linked cases}

The empirical research on which this analysis is based was organized as a contrastive case study. Case studies offer concrete context-bound knowledge (Flyvbjerg 2004). According to Kitay and Callus (1998), case studies are the best method of researching power relations and complex social interactions, particularly when these are in flux. A central feature of case studies is triangulation of data, which enables a deeper understanding of the phenomenon under research (Flyvbjerg 2004). Following the case study logic and taking into account the need to triangulate data, several types of data were collected parallel with the analysis. The research process and the empirical material are described in detail in the endnotes. ${ }^{5,6}$

As trade union movements in the two contexts are very different, direct comparisons are not only meaningless but impossible. Instead, the two cases offer a means to contrast the findings concerning each case, thus producing more situated accounts and interpretations. In this study, the FCTU is approached as one case and the Estonian trade union movement forms another case. As regards Estonia, the choice of including several trade unions in the study instead of one, and looking at the Estonian trade union movement as an entity, is motivated by the weak position of Estonian trade unions. The FCTU is chosen as a case because the construction sector is one of the most immigrant-dense sectors of the labor market. Furthermore, the construction industry forms a highly interesting case because its structural changes, such as subcontracting, are intertwined with questions of international mobility of workers and employers (e.g., Lillie \& Greer 2007).

As mentioned earlier, Estonian mobility to Finland is facilitated by both countries now belonging to the EU, the Schengen Area, and the Eurozone. The emergence of a translocal labor market has further been facilitated by the linguistic closeness of Estonian and Finnish and by the short distance: the $80 \mathrm{~km}$ crossing between Tallinn and Helsinki can be covered by ferry in under two hours. In the last few years, a translocal labor market has emerged in the Helsinki-Tallinn area, and Estonians are now the 
largest group of foreign nationals in Finland (Statistics Finland 2011). In the Finnish capital area, an estimated one-third of construction workers are of foreign-mainly Estonian-origin (Source: the FCTU). For instance, 64\% of the workers undertaking facade renovations in Helsinki in 2010 were of foreign origin, Estonians forming the largest foreign group (ibid.). A large share of the Estonian workers, especially in the construction sector, commute between Estonia and Finland, looking for job opportunities, higher wages, and generally a better quality of working life (Alho 2010). The translocal Helsinki-Tallinn labor market can be compared with other European border regions where migrants from countries with lower wages and living standards frequently cross national borders for work in the wealthier country (cf. Krings 2009). The average monthly gross wages and salaries for a full-time worker in year 2011 were 839 Euros in Estonia, whereas in Finland the figure was 3111 Euros (Statistics Estonia/Statistics Finland). In 2011, Finnish purchasing power parity was approximately twice as high as that of Estonia (OECD Statextracts 2012).

According to FCTU estimates, there are 170,000 workers in the construction sector, of whom 100,000 are employees, 20-25\% of them migrant workers, i.e., 25,000-30,000 workers. FCTU estimated in January 2013 that the Estonians were the largest foreign group with 10,000-20,000 workers (Hufvudstadsbladet Jan 19, 2013). The majority of this category works on a temporary basis in Finland. They are posted workers, but also hired agency workers, self-employed, or workers directly employed by Finnish or Estonian employers. There are no statistics on the dispersion of these workers in these different categories. According to FCTU sources, it is possible that the amount of Estonian and other foreign workers will continue to increase in future (e-mail response from an FCTU official on Aug 6, 2012). The aforementioned figures are high in a country where the foreign-born population living permanently in the country is only a little more than $5 \%$ of the total population.

In earlier research, particular trade union histories and identities are recognizedin addition to the national industrial relations system-as variables influencing trade union strategy (e.g., Marino 2012). In Estonia, the low membership is related to the difficulty Estonian trade unions have in re-identifying themselves after the collapse of the Soviet Union. It is also related to the variance in degree of trust in trade unions in the respective countries. According to the European Social Survey (for 2010), two out of three Finns trust that trade unions have at least some influence over decisions that affect working conditions, while fewer than one in five do so in Estonia. Indeed, nearly $40 \%$ of Estonians state that they work in workplaces where there are no unions present (ibid.).

The effect of immigration on receiving countries has been one of the most conflictridden issues in European societies (e.g., Ervasti et al. 2012, p. 4). The migration histories of the two countries are marked by their political and economic histories. During the period 1945-1991, when Estonia was annexed to the Soviet Union, hundreds of thousands of migrants from other parts of the Soviet Union were relocated to the country. For native Estonians, the non-Estonian-speaking migrants who came to form nearly $40 \%$ of the country's population presented a threat of cultural Russification (Zetterberg 2007). During the same time period, immigration to Finland was virtually nonexistent, gradually booming only in the 1990s and 2000s. As previously stated, evidence exists that such national experiences affect the collective memory and perceptions of actors involved in migration management (Menz 2011, pp. 23-75). These experiences might influence actors such as trade unions to perceive immigration as a threat or as 
an opportunity. Despite a strengthening public anti-immigration political discourse (Haavisto 2011, p. 200), attitudes toward immigration in Finland (much like in other Scandinavian countries) have on a general level been comparatively positive in a European context (Ervasti et al. 2008, p. 197).

\section{The Finnish Construction Trade Union: control-oriented strategies combined with some mobilizing strategies}

The FCTU holds one key power resource by default, as construction work cannot be relocated to low-wage countries in order to save costs, as in some industry sectors. Its potential for defending national labor standards and rights is strengthened by the high density of union membership in the Finnish construction sector: the interviewed FCTU representatives claimed that in 2007 around $70 \%$ of employees working "permanently" in the sector were FCTU members. The FCTU also has an institutionalized access to tripartite negotiating, giving it ample opportunities for influence.

Despite its historically strong position, the FCTU fears that the transnationalization of the national labor markets adversely affects the labor market situation from its standpoint, in terms of decreased wages and other forms of competition from abroad. This fear is shared by many trade unions in Northern and Western Europe, especially after the EU accessions of 2004, when several former Eastern Bloc countries became EU members (e.g., Hardy et al. 2012). The FCTU has the goal of preventing the formation of a two-tier labor market based on nationality or ethnicity, a question that is linked to the FCTU's power resources. Trade union strategies have to be understood in relation to employer strategies. In this regard, it is fruitful to refer to the transnational practices that enterprises have adopted. In the context of Estonia and Finland, construction enterprises can circumvent Finnish national regulations by operating in the Finnish construction sector via Estonia and other EU countries where employer costs are lower than in Finland (cf. Lillie \& Sippola 2011). Furthermore, even if collective agreements apply to all workers in Finland irrespective of nationality, there is evidence of underpayment of migrants due to lack of monitoring of working conditions (Alho 2010). In addition, employers can, within the law, exert downward pressure on wages, as the collective agreements (which are nationally binding in Finland) stipulate only the minimum wage levels in different wage brackets. Many Finnish construction workers are not prepared to accept wages that only match the minimum stipulated in the collective agreements, whereas a migrant worker coming from a low-wage country might consider the same wage more acceptable.

The work of Estonians in the Finnish construction sector is characterized by crossborder commuting in an emerging translocal labor market between the respective countries. This is problematic for the FCTU, as commuting workers rarely become members. Neither the FCTU nor the state authorities have control regarding their working conditions. The FCTU defines immigrant construction workers as exploited. According to Paananen (1999), the FCTU labeled foreign workers as exploited at the shift of 1990s out of economic self-interest, so that it could defend its demands to restrict the amount of foreign workers with a moral and altruistic argument.

Evidence certainly exists of underpayment and other problems regarding the working conditions of migrant workers in Finland (Wrede \& Nordberg 2010). The FCTU 
also points out considerable problems in the housing conditions of foreign construction workers. In addition, the apartments or habitations are in some cases owned by the employers or agencies, who apply overpriced rents. Nevertheless, the term exploitation does not always correspond to the subjective experience of those migrant workers in whose country of origin the living and working conditions are at a lower standard (cf. Krings 2009; Piore 1979).

Previous research has argued that the FCTU-notwithstanding the transnationalization and opening up of the national borders-still targets its strategies in the frame of the nation state and has difficulty coping with the transnational practices applied by employers (Lillie \& Greer 2007; Lillie \& Sippola 2011). The FCTU stresses that it is not against the use of foreign workers as such, but opposes those practices where working conditions are undercut by the use of foreign labor. This stance is in accordance with the viewpoint of Finnish trade unions on a general level that immigration is a reality and should be accepted as long as the process happens in a controlled fashion and does not lead to inequalities in the labor markets based on ethnicity or nationality (Alho 2008; Ristikari 2013).

Many of the interviewees expressed that labor migration is a natural part of the construction industry, and some referred to historical examples of Finnish construction workers being employed in various construction projects abroad. They also highlighted that the FCTU has been successful in defending migrant workers-in some cases even nonmembers-with regaining withheld wages or other work-related benefits. The FCTU emphasizes that they, together with the Finnish authorities, do not have sufficient resources to control whether posted workers in reality pay taxes to their home country. According to the FCTU, this situation gives a comparative advantage to foreign enterprises. The FCTU is in a challenging situation as regards the traditional trade union demand of equal pay for equal work. So, what are its strategies in this situation?

The FCTU has outspokenly resisted political demands over loosening restrictions for third country nationals to enter the Finnish labor markets. Its argument is that there is no lack of workforce in the construction sector, and that there are problems regarding the working conditions of migrant workers (Alho 2010). However, as regards intra-EU and The European Economic Area labor immigration, the FCTU has no direct means to exclude foreign workers or enterprises from entering the Finnish construction sector. In addition, it has little means to include temporary labor migrants as members, who are generally not interested in membership, owing to their temporary stay. However, as an institutionally strongly embedded trade union in a CME context, it has power resources to influence the jurisdiction, as it perceives to be in its favor, in questions of transnational labor mobility. An illuminating example of its strategy is the successful lobbying of the tax number. According to the FCTU, its cooperation with the employers' organization, the Confederation of Finnish Construction Industries RT, and its personal contact with the social democrat MP, Jukka Gustafsson, were essential for successful lobbying (YLE News/Morning TV May 31, 2012). The tax number is an interesting example, as it represents an administrative strategy that has both inclusive and exclusive elements regarding foreign workers. The tax number proves that the individual worker has registered with the tax authorities. It has been compulsory for all construction workers since September 2012. The number, which facilitates monitoring, has to be attached to the identification and must always be visible when working on a construction site. The foreign applicant must be able to present a valid residence permit (if they come from 
outside the EU/EEA) and a work contract in order to receive a tax number. The FCTU has also the legal right to pressure those employers who do not follow the collective agreements by boycotts (Alho 2012; Lillie \& Sippola 2011, p. 298). When a boycott occurs, FCTU members are asked not to work for the boycotted firm. This pressure strategy, the goal of which is to force the employer to respect the collective agreements, is most often targeted at foreign construction enterprises (ibid.). Although the majority of undocumented workers in construction are natives, growing numbers of foreign workers are entering the undocumented labor market (Cremers 2006). In this situation, the FCTU has pushed for legislation that facilitates control and monitoring. The employers' association agrees with the FCTU that undocumented work has adverse socioeconomic effects. The employers' association also has self-interest in preventing social dumping, as its member enterprises are negatively affected in cases where foreign enterprises undermine Finnish collective agreements.

The FCTU has backed its demands for new control-oriented legislation-including more effective enforcement-by a media strategy that has problematized the use of a foreign workforce. During recent years, the FCTU has also successfully advocated other legislation that facilitates the control of particularly foreign workers and enterprises.

Trade union strategies vis-à-vis immigration and migrant workers are often divided on the inclusion/exclusion axis (e.g., Penninx \& Roosblad 2000). Many strategies can with good reason be placed in either category. However, strategies-such as the tax number-often have complex indications, and they comprise both inclusive and exclusive elements. For instance, requiring the tax number includes the foreign workers in the regulated Finnish labor market, and as a consequence also includes them in some forms of social security, whereas it-at least in principle-excludes undocumented foreign workers from the labor market. According to an Estonian construction entrepreneur, Haakan Nomm, the tax number means that "the wild west era in the Finnish construction sector is coming to an end" (Baltic Business News Mar 21, 2012), the "wild west era" referring to uncontrolled work from Estonia. Baltic Business News (ibid.) argues that the tax number is "designed to force Estonians out of the Finnish construction market." The FCTU assesses that the tax number might initially "to some degree" reduce the amount of Estonian workers in the Finnish construction sector (e-mail response from an FCTU leader, August 2012). In other words, the FCTU is aware of the protectionist implications of the strategy. One of the FCTU leaders assesses that the tax number will imply more work opportunities for Finnish construction workers (YLE News Jun 21, 2012).

The strategies of the FCTU are control oriented and have a strong administrative bias. Notwithstanding the increasing share of Estonian and other foreign workers, the FCTU does not perceive migrant workers as a source of renewal or revitalization as the US unions do. There are no large-scale comprehensive mobilization campaigns, nor is there a discourse that would interpret migrants as a source of renewal. The lack of extensive mobilization campaigns is explained partly—as previous research (Lillie \& Sippola 2011) also suggests-by mobilizing efforts being costly, as a large share of migrant construction workers are temporarily in Finland. An additional explanation for the lack of such mobilization campaigns could be institutional and path dependency related, namely the Ghent system, where unions have by default been attractive to employees because of the administration of unemployment funds. According to Frege and Kelly (2006, p. 7), union strategies are most strongly oriented toward mobilization in countries where the institutional position of unions is weakest. Finnish trade unions 
have-in an institutionally strong position—gained a high density without needing to divert excessive resources to direct mobilization.

The FCTU perceives the increasing transnational mobility under current circumstances as a threat rather than an opportunity for strengthening its power resources. One central strategy of the FCTU is its demand for more state intervention in controlling working conditions. The demand is logical, as monitoring working conditions consumes union resources. The FCTU has also emphasized that more young people should be educated into the construction sector. This demand is also logical from a trade union perspective: it is by default less costly for the FCTU to mobilize workers permanently living in the country than foreign workers whose stay is characterized by temporariness. The FCTU shop stewards interviewed for this research indicated that recruitment is challenged by foreign workers working in their own groups and often having a foreign employer. The difficulties were enhanced by the lack of a common language, although Estonian workers were seen as a relatively easy target group, owing to the closeness of the Estonian and Finnish languages. The shop stewards also expressed that Estonian workers in some cases feared their employer's reaction if they joined FCTU, or had reservations toward unionism, as trade unions were part of the repressive Soviet regime in the former Estonia.

There has been some change in strategy, as the FCTU has allocated increasing resources to servicing and raising awareness of migrant workers in recent years. Primarily, this has meant hiring a Russian-speaking official, translating more information material into foreign languages, and establishing a trade union branch for its members with a "foreign" background (the branch operates mainly in Estonian and Russian). The FCTU has also established an information office in the capital of Estonia, where it informs prospective Estonian emigrants to Finland about work-related issues and membership of the FCTU. The information office has, according to the FCTU, led to some 150 Estonians joining as FCTU members. The FCTU also gave "some" financial assistance to the Estonian Construction Union. This was not a successful strategy, as the Estonian sister union went bankrupt in the early 2000s, which highlights the difficulty of transnational trade union strategies. As regards strategy, it is important to note that-owing to the universally binding collective agreements in the Finnish CME context-even those trade union strategies that are not explicitly aimed at migrants can defend and ameliorate the position of migrant workers.

The FCTU faces challenges regarding increased transnational mobility, although its position has been facilitated by its comparatively strong power resources, a relatively favorable economic situation in the Finnish construction sector, and also its increased efforts in mobilizing and informing migrant workers. Nevertheless, according to Kouvonen (2012), wage development was slowed down between 2006 and 2010 in the capital area of Helsinki in the construction and cleaning sectors which "appears to be related" to the fact that these sectors employ a remarkable share of migrant workers.

However, wages have not fallen in the Finnish construction sector. Furthermore, construction sector unemployment figures are lower and wages higher in the capital area, despite the fact that it employs more migrant workers than other parts of the country. From this perspective, it can hardly be argued that the influx of foreign workers into the Finnish construction sector would have to lead to a large-scale social dumping, although the phenomenon poses veritable challenges for the FCTU. 
According to the FCTU, migrants who live permanently in Finland join the FCTU to the same degree as native Finns. Thus, the challenge regarding organizing migrants is temporariness and not ethnicity as such, although linguistic and sociohistorical aspects pose some difficulties for the successful recruitment of migrant workers. Migrant workers are also-despite still being underrepresented as FCTU members-increasingly joining the FCTU, as Table 1 indicates.

Table I Membership figures of the Finnish Construction Trade Union (FCTU).

\begin{tabular}{lccccccccccc}
\hline Year & 2002 & 2003 & 2004 & 2005 & 2006 & 2007 & 2008 & 2009 & 2010 & 2011 & 2012 \\
\hline $\begin{array}{l}\text { Total } \\
\text { membership }\end{array}$ & 80,870 & 80,212 & 80,659 & 80,922 & 82,096 & 84,954 & 83,526 & 88,031 & 86,821 & 86,945 & 88,917 \\
\hline $\begin{array}{l}\text { Immigrant } \\
\text { members }\end{array}$ & 376 & 465 & 601 & 657 & 816 & 1,251 & 1,788 & 1,441 & 1,926 & 2,585 & 3,477 \\
\hline $\begin{array}{l}\text { Percentage of } \\
\text { immigrants in }\end{array}$ & 0.5 & 0.6 & 0.7 & 0.8 & 1.0 & 1.5 & 2.1 & 1.6 & 2.2 & 3.0 & 3.9 \\
\begin{tabular}{l} 
membership \\
\hline
\end{tabular} & & & & & & & & & & & \\
\hline
\end{tabular}

Source: The FCTU membership register.

Nevertheless, the estimated number of foreign construction workers was between 25,000 and 30,000 in 2010, and the number of migrant members was approximately 3,500 in 2012. On the basis of these figures, the density of migrant construction workers is somewhere between 12 and $14 \%$, which is far below the national average in Finland. ${ }^{7}$

\section{The Estonian Trade Union Movement: immigration as a threat, emigration as a problem}

In order to understand the situation of Estonian trade unions, it is necessary to give a brief overview of Estonian history and industrial relations. During the Soviet occupation of Estonia, trade unions formed a part of the Soviet regime. The Communist party controlled unions and membership was virtually compulsory. Social security and access to various consumer goods required trade union membership, which further enhanced membership, and trade union density was close to 100\% (cf. Feldmann 2008).

When Estonia gained its independence from the Soviet Union in 1991, the old Soviet-era unions were not suited for a market economy: they were designed for a totally different epoch and purpose. According to the Estonian informants, trade unionism retains image problems from the Soviet-era, as many Estonians even today associate trade unionism with repression. It has been hard for unions to tackle this image and portray themselves as genuine interest organizations. (interviews; Sippola 2009). After its independence, Estonia implemented radical market liberal policies (Feldmann 2008). The changes affected also Estonian industrial relations so that there has been little room for trade unions to influence the development in Estonia (ibid.).

According to the informants, the ethos of the last two decades has been individualistic. Collective action, such as trade unionism, has been met with suspicion. Some 
of the interviewees also pointed to rifts inside the union movement that have impeded the search for viable strategy. Trade union density in Estonia has been in steady decline during the last two decades and was $8 \%$ in 2012, far below the OECD average (OECD Statextracts 2012). There has, however, been some rise in density in sectors such as transport, aviation, and seafaring (interviews). The low density is also related to Estonian trade unions having little influence in Estonian society. Employers rarely accept trade unions as negotiating partners, and tripartism is virtually nonexistent. Social dialogue between unions and employers is further hindered by the low representativeness of the Estonian Central Employers' Organization (EETK) among employers (Feldmann 2008, pp. 332-333). In other words, unions generally lack organized negotiation partners.

During the Soviet occupation, immigration was an effect of the Soviet invasion, as hundreds of thousands of migrants from other parts of the Soviet Union migrated into the country. A suspicion toward immigration was echoed in the interviews conducted for this article. Some of the interviewed Estonian union officials feared that Estonian culture would be threatened by immigrants, who in some cases would not adapt to or integrate into Estonian society. Some expressed a fear that immigrants might be an economic burden on Estonian society. This stance is also visible in the following quote from The Estonian Trade Union Confederation proposals for policy formation in 2011-2015 (emphasis added).

"Estonia needs, in both the private and state sectors, a wage policy that prevents the qualified work force from leaving Estonia as well as avoiding the need to bring in migrant workers, which in the longer term would be a big additional burden for the whole of society."

In the interviews, the Estonian union officials also referred to the "traditional" trade union fear of employers using immigrants to undercut working conditions. These Estonian fears are also visible in the previously mentioned European Social Survey, which indicates that Estonians have a rather cautious view on immigration. This is despite the demographic challenges currently faced by Estonia related to the aging population and emigration (on these challenges, see e.g., Söderling 2011, p. 71). According to the interviewees, the Estonian state should place more emphasis on vocational training for Estonians in those industry sectors that lack labor, instead of facilitating immigration (the same vision as that advocated by the FCTU).

The question of large-scale immigration into Estonia will remain rather hypothetical for the foreseeable future, as Estonia is a low-wage country by European standards. As regards labor mobility, the main issue for the Estonian trade unions is emigration, not immigration. The interviewees explained emigration as a response to the low wage levels and working conditions, and the generally weak position of the employee in Estonia. We find accounts of nineteenth century trade unionists perceiving-based on neoclassical economistic reasoning - that emigration would be beneficial for organized labor, as it decreases the supply of labor (Clements 1955). In contrast, the interviewees rather perceived emigration as a problem for the Estonian nation in terms of the nation losing a considerable share of its "active" population (although some claimed that emigration to Finland had put some upward pressure on Estonian wage levels). The interviewees also argued that migration or commuting to Finland poses difficulties for social and family life, as many of the workers have families in Estonia who they seldom see. The informants pointed out that work in Finland meant downward occupational mobility for many Estonians, despite the higher wages. Several interviewees expressed the hope 
that Estonian workers might be influenced by trade unionism in Finland and hence be more supportive of trade unions when/if returning to Estonia.

The Estonian trade unions had no strategies in relation to transnational labor mobility, with the exception of publicly opposing increased immigration and striving for better working conditions and social security, which the interviewees claimed would deter Estonians from working in Finland. Some individual union officials shared knowledge and experience regarding issues on labor mobility with trade unionists in other countries.

Neither the unions nor their central organizations have strategies targeted at immigrants in Estonia, unless Russian speakers are defined as an immigrant group, as the unions publish information in both Estonian and Russian. In the difficult situation where union density has decreased to $8 \%$, the main concern for the Estonian trade union movement seems to be the question of how to organize Estonians into unions. There is a circle between the low density and the lack of societal influence: unions experience difficulty in attracting and holding on to members owing to their lack of power resources, which in turn are weakened by a diminishing member base. In the interviews conducted in 2012, the informants expressed some hope regarding the Baltic Organizing Academy (established in 2012), which involves support given by Scandinavian trade unions to Estonian and other Baltic trade unions in terms of resources for organizing the work force as trade union members. It remains to be seen whether this kind of action can strengthen the weak power resources of the Estonian trade union movement.

The interviewees had no statistics or data on the amount of migrants working in the sectors their unions represent, and the issue of immigration did not seem to be a central concern. The main concern of the unions was the weak position of the Estonian trade union movement. Some union officials claimed that an uncertain number of migrant workers posted from Russia were working in the shipyards. One interviewee referred to a case of Ukrainians overstaying their tourist visas and working undocumented in Estonia. Some of the interviewees claimed that there were an unknown number of migrant construction workers from the former Eastern Bloc countries, an assessment shared with the Estonian tax authorities, which had identified "illegal" workers from Bulgaria, Ukraine, and Latvia on construction sites (Baltic Times Mar 30, 2012). Some migrants were said to be working in banking and IT, i.e., in sectors without a trade union presence in Estonia.

The Estonian trade union movement has no influence over questions of transnational labor mobility. Estonian trade unionists have a perception of the phenomenon, but it can hardly be argued that Estonian unions would have a strategy toward this question, as their action is limited to sporadic public statements and information sharing by individual trade unionists in Estonia and abroad. Nevertheless, a concrete information sharing strategy by the Estonian Transport Workers Union was evidenced when it informed its members working as bus drivers in Finland to join Finnish bus drivers in a strike in Finland. The lack of a coherent strategy reflects the generally weak power resources of Estonian trade unions. On the basis of the research material, the main question for the Estonian unions seems to be how to mobilize Estonian workers into unions, and how to become accepted as a negotiation partner by the state and employers (who sometimes dismiss trade union claims with a reference to a small trade union membership). In questions of transnational mobility, the Estonian trade union movement is a stakeholder rather than an actor. 


\section{Conclusions and discussion}

Previous research by Krings (2009) suggests that the national model of industrial relations system of coordinated market economies/liberal market economies is of central importance as an explanatory factor regarding the strategy of trade unions, so that trade unions in a CME context (in this research, Finland) would be fairly restrictive towards immigration, whereas unions in LMEs (in this research, Estonia) would advocate a more liberal stance, with a stronger emphasis on reaching out to migrant workers. This holds to a large extent for the case of Finland, as regards the Finnish Construction Trade Union (FCTU), but not for the Estonian case.

The FCTU has reacted to the opening up of the national labor market in a rather protectionist manner, which is in accordance with Krings' model. Nevertheless, it is important to underline that the FCTU perceived temporary forms of work from abroad as a problem, in contrast to permanent labor immigration, which it did not consider a problem. Labor migration is increasingly temporary in character, and immigration, or transnational mobility, now takes place in a postindustrial and fragmented labor market setting. The inclusion of an Estonian migrant working temporarily in Finland for an Estonian subcontractor appears challenging from a traditional trade union perspective that assumes permanent residence in the country, as was more often the case in earlier waves of migration. The inclusion of migrants from Estonia (and other post-Soviet states) is also challenging because Estonians do not come from a country with a wellorganized union movement and seldom hold union membership in their home country.

In terms of the opening up of the national labor market, the FCTU fears losing control of working conditions, which would have a negative effect on the unions' power resources. For the FCTU, reacting to labor mobility is an attempt to defend the coordinated market economy from being transformed into a liberal market economy, in which its institutional position and power resources would be threatened. As has been shown in this article, this is a rather difficult task, which is illuminated, for instance, by the difficulty of controlling the working conditions of commuting Estonian workers. The strategies of the unions can be framed on the basis of the distinction between mobilizing strategies and strategies along the governmental dimension and (see page 144 ) in the manner illustrated by Table 1.

Table 2 Trade union strategies regarding transnational labor mobility.

\begin{tabular}{lll}
\hline & Finnish Construction Union (FCTU) & Estonian trade union movement \\
\hline Mobilizing strategies & $\begin{array}{l}\text { Emerging (more effort to inform and } \\
\text { include foreign workers as members) }\end{array}$ & $\begin{array}{ll}\text { No mobilizing strategies directed } \\
\text { at migrants }\end{array}$ \\
\hline $\begin{array}{l}\text { Strategies along the } \\
\text { governmental dimension }\end{array}$ & $\begin{array}{l}\text { Strong: the union has the possibility to } \\
\text { influence legislation and regulate labor } \\
\text { mobility. Emphasis on regulating mobility }\end{array}$ & $\begin{array}{l}\text { None, except for sporadic public } \\
\text { statements }\end{array}$ \\
\hline
\end{tabular}

As the table indicates, the FCTU has to some degree changed its strategies toward a more inclusive and mobilizing direction. The FCTU has realized that control-oriented measures are not enough to control the labor market situation as regards the diversification of labor mobility patterns, of which the emergence of a translocal labor market 
between Finland and Estonia is a prime example. This change in strategy does not undermine Krings' theory that trade unions in CME countries apply and advocate more restrictive strategies than unions in LMEs. Instead, the change in the FCTU's strategy should be interpreted as the Finnish construction sector opening up to competition from abroad, and the union reacting to this by adding some new inclusive strategies to its repertoire.

Nevertheless, the VoC approach should be applied cautiously in relation to trade union strategy as regards labor mobility for two reasons. First, even in CME countries such as Finland, specific sectors, such as construction-besides being challenged by translocal commuting and other forms of temporary migration-are not as strongly coordinated according to the national logic as in the past (as also the findings of Bechter et al. 2012 indicate). Second, the particular context-bound migration histories of the nations where trade unions operate influence unions' stance toward labor mobility, as has been especially shown in the case of Estonia.

Despite the emergence of a translocal labor market between the capital areas of Helsinki and Tallinn, the FCTU can still influence labor mobility through national arrangements, e.g., by negotiating nationally binding collectives (that apply even to migrant workers in Finland), by influencing national jurisdiction, and by being able to some degree to attract migrant workers as members. One can with good reason assess that the FCTU's strategies have, for their part-in spite of the problems-hindered a large-scale social dumping of working conditions through the use of foreign workers; wages in the construction sector have increased in the capital area of Finland despite the large and increased foreign workforce (see Kouvonen 2012 for wage levels).

The results underline the importance of concrete trade union strategies that cut across national borders (such as the information point in Estonia) in addition to national strategies. To some extent, these strategies improve the vulnerable situation of migrant construction workers in Finland. The results demonstrate the practical difficulties of imposing translocal trade union strategies across two, fundamentally different, institutional settings. To begin with, there is no counterpart to the FCTU in Estonia. Nevertheless, the FCTU-which operates in an increasingly translocal and transnational context—can, despite these challenges, influence the process of labor mobility somewhat to its favor owing to its nationally strong institutional position.

Estonia can no doubt be characterized as an LME-or even a neo-liberal market economy. However, the Estonian trade union movement does not hold a liberal stance toward immigration, as a trade union movement in an LME would be inclined to do according to Krings (2009). The Estonian trade union movement has an outspokenly restrictive stance toward immigration. Neither do the Estonian unions have any strategies aimed at mobilizing immigrants. On the basis of the interviews conducted with Estonian trade union officials, it is evident that the particular immigration history related to the Soviet invasion of Estonia plays a role. The interviewees perceived immigration to Estonia as an economic and cultural threat, not as an opportunity. Indeed, the historically rooted fear of the Russification of Estonia, combined with the historical legacies of politically controlled Soviet-era trade unionism, contributes to a difficult outlook for Estonian trade unions as regards dealing with labor mobility. It seems that the restrictive stance is also explained-in contrast to the argument about the liberal migration strategies of LME trade unions-by the very weak position of the Estonian trade union movement. It is not likely that the Estonian trade union movement would have sufficient 
power resources to influence the circumstances under which immigration to Estonia would take place, or have resources for mobilizing immigrants into unions. Instead, the Estonian trade union movement appears to be an outsider as regards migration policy and is still looking for avenues through which to institutionalize power resources to gain increased influence in the coordination of national labor markets. For a broader European context, the lesson from this study is that-despite a deepened European integration-there is an immense variance in trade unions' possibilities of influencing transnational labor mobility.

\section{References}

Ahtiainen, L. (2009) Palkansaajien järjestäytyminen Suomessa vuonna 2009 [The organization of wage and salary earners in Finland year 2009]. Helsinki: Ministry of Employment and the Economy.

Alho, R. (2008) Maahanmuuttajat suomalaisessa ay-liikkeessä: tapaus PAM [Immigrants in the Finnish trade union movement: the case of the Service Union United], in M. Helander (ed.) Going Global. Ay-liikkeen menestysresepti globaalissa ajassa? [Going Global. A Recipe of Success for the Trade Union Movement?] Helsinki: Minerva kustannus Oy, pp. 283-329.

Alho, R. (2010) Maahanmuuttajien kokemukset ja ammattiliittojen näkemykset työehtojen polkemisesta Suomessa [Immigrants' experiences and trade unions' perceptions of social dumping in Finland], in S. Wrede \& C. Nordberg (eds.) Vieraita työssä: työelämän etnistyvä eriarvoisuus [Strangers in Work: The Ethnifying Inequality in Working Life]. Helsinki: Gaudeamus, pp. 93-121.

Alho, R. (2012) 'Rakennusliiton ja Palvelualojen ammattiliiton maahanmuutto- ja maahanmuuttajastrategiat' [The immigration and immigrant strategies of the Finnish Construction Trade Union and the Service Union United], Työelämän tutkimus 10(1): 38-54.

Bechter, B., Brandl, B. and Meardi, G. (2012) 'Sectors or countries? Typologies and levels of analysis in comparative industrial relations', European Journal of Industrial Relations 18(3): 185-202.

Behrens, M., Hamann, K. and Hurd, R. (2006) Conceptualizing labour union revitalization, in C. Frege \& J. Kelly (eds.) Varieties of Unionism: Strategies for Union Revitalization in a Globalizing Economy. Oxford: Oxford University Press, pp. 11-29.

Bengtsson, E. (2013) 'Swedish Trade Unions and European Union Migrant Workers'. Journal of Industrial Relations 55(2): 174-189.

Bergholm, T. (2003) A Short History of SAK [The Central Organisation of Finnish Trade Unions]. SAK.

Brickel, K. and Datta, A. (2011) Introduction, in K. Brickel \& A. Datta (eds.) Translocal Geographies. Farnham: Ashgate, pp. 3-22.

Briggs, V. M. (2001) Immigration and American Unionism. Ithaca, NY: Cornell University Press.

Böckerman P. and Uusitalo, R. (2006) 'Union membership and the erosion of the Ghent system: Lessons from Finland', British Journal of Industrial Relations 44(2): 283-303.

Clements, R. V. (1955) 'Trade unions and emigration, 1840-80', Population Studies: A Journal of Demography 9(2): 167-180.

Cremers, J. (2006) 'Undeclared Labour in the Construction Industry: Country reportFinland, June '06'. European Institute for Construction Labour Research CLR.

Ervasti, H., Fridberg, T., Hjerm, M. and Ringdal, K. (2008) Nordic Social Attitudes in a European Perspective. Cheltenham: Edward Elgar. 
Ervasti, H., Goul Andersen, J., Fridberg, T. and Ringdal, K. (2012) The Future of the Welfare State: Social Policy Attitudes and Social Capital in Europe. Cheltenham: Edward Elgar.

Feldmann, M. (2008) The origins of varieties of capitalism: lessons from post-socialist transition in Estonia and Slovenia, in B. Hancké, M. Rhodes \& M. Thatcher (eds.) Beyond Varieties of Capitalism: Conflicts, Complementarities and Institutional Change in European Capitalism. Oxford: Oxford University Press, pp. 328-350.

Flyvbjerg, B. (2004) Five misunderstandings about case-study research, in C. Seale, G. Gobo, J. F. Gubrium and D. Silverman (eds.) Qualitative Research Practice. London: Sage, pp. 420-434.

Frege, C. and Kelly, J. (eds.) (2006) Varieties of Unionism. Strategies for Union Revitalization in a Globalizing Economy. Oxford: Oxford University Press.

Haavisto, C. (2011) Conditionally One of 'Us'. A study of Print Media, Minorities and Positioning Practices. PhD thesis, University of Helsinki.

Hall, P. and Soskice, D. (eds.) (2001) Varieties of Capitalism: The Institutional Foundations of Comparative Advantage. Oxford: Oxford University Press.

Hancké, B., Rhodes, M. and Thatcher, M. (2008) Beyond Varieties of Capitalism: Conflict, Contradictions, and Complementarities in the European Economy. Oxford: Oxford University Press.

Hardy, J., Eldring, L., Schulten, T. (2012) 'Trade union responses to migrant workers from the 'new Europe': a three sector comparison in the UK, Norway and Germany', European Journal of Industrial Relations 18(4): 347-363.

Haus, L. (2002) Unions Immigration and Internationalization. New Challenges and Changing Coalitions in the United States and France. New York: Palgrave Macmillan.

Holgate, J. (2005) 'Organizing migrant workers: a case study of working conditions and unionization in a London sandwich factory', Work, Employment \& Society 19(3): 463-480.

James, P. and Karmowska, J. (2012) 'Unions and migrant workers: strategic challenges in Britain', Transfer 18(1): 201-212.

Johansson, J. (2012) 'Swedish employers and trade unions, varieties of capitalism and labour migration policies', Nordic Journal of Migration Research 2(4): 325-334.

Kitay, J. and Callus, R. (1998) The role and challenge of case study design in industrial relations research, in K. Whitfield and G. Strauss (eds.) Researching the World of Work: Strategies and Methods in Studying Industrial Relations. Ithaca: Cornell University Press, pp. 101-112.

Korpi, W. (1998) Power resources approach vs. action and conflict: on causal and intentional explanations in the study of power, in J. S. O'Connor \& G. M. Olsen (eds.) Power Resource Theory and the Welfare State: A Critical Approach. Toronto: University Press, pp. 37-65.

Krings, T. (2009) Organised Labour and Migration in the Global Age: A Comparative Analysis of Trade Union Responses to Migrant Labour in Austria, Germany, Ireland and the UK. PhD thesis, Dublin City University.

Kyntäjä, E. (2011) Viron- ja Venäjänkielisten maahanmuuttajien kokemukset työyhteisön ja ammattiliiton jäsenenä [Estonian and Russian speaking migrants experiences as members of work places and trade unions.], in M. Helander (ed.) Totta toinen puoli? Työperäisen maahanmuuton todelliset ja kuvitellut kipupisteet. [Partly True? The Real and Imagined Problems of Labour Immigration] Helsingfors: Svenska social- och kommunalhögskolan, pp. 59-84.

Lillie, N. and Greer, I. (2007) 'Industrial relations, migration and neo-liberal politics: the case of European construction sector', Politics \& Society 35(4): 551-582.

Lillie, N. and Sippola, M. (2011) 'National unions and transnational workers: the case of Olkiluoto 3, Finland', Work, Employment and Society 25(2): 292-308.

Ma, E. K. (2002) 'Translocal spatiality', International Journal of Cultural Studies 5(2): 131-152.

Marino, S. and Roosblad, J. (2008) 'Migration and trade unions. A comparison between Dutch and Italian trade unions' actions and strategies', Transfer 14(4): 625-638. 
Marino, S. (2012) 'Trade union inclusion of migrant and ethnic minority workers: Comparing Italy and the Netherlands', European Journal of Industrial Relations 18(1): 5-12.

Menz, G. (2011) The Political Economy of Managed Migration. Nonstate Actors, Europeanization and the Politics of Designing Migration Policies. Oxford: Oxford University Press.

Milkman, R. (2010) Introduction, in R. Milkman, J. Bloom \& V. Narro (eds.) Working for Justice. The L. A. model of Organizing and Advocacy. Ithaca: Cornell University Press, pp. 1-19.

Mrozowicki, A., Roosalu, T. and Bajuk Sencar, T. (2013) 'Precarious work in the retail sector in Estonia, Poland and Slovenia: trade union responses in a time of economic crisis', Transfer 19(2): 267-278.

Mulinari, D. and Neergaard, A. (2004) Den nya svenska arbetarklassen. [The New Swedish Working Class]. Umeå: Boréa.

Nash, J. (2001) Labor Struggles: Gender, Ethnicity, and the New Migration, in I. Susser \& T.C. Patterson (eds.) Cultural Diversity in the United States. Malden, MA: Blackwell Publishers Ltd. pp. 206-228.

Paananen, S. (1999) Suomalaisuuden armoilla. Ulkomaalaisten työnhakijoiden luokittelu. [At the mercy of Finnishness: classification of foreign labour market recruits]. PhD thesis, University of Helsinki.

Penninx, R. and Roosblad, P. (eds.) (2000) Trade Unions, Immigration, and Immigration in Europe 1960-1993. New York: Berghahn Books.

Piore, M. J. (1979) Birds of Passage. Migrant Labor and Industrial Societies. Cambridge: Cambridge University Press.

Ristikari, T. (2013) Finnish Trade Unions and Immigrant Labour. PhD thesis, University of Tampere.

Roosblad, J. (2002) Vakbonden en immigranten in Nederland (1960-1997). PhD thesis. University of Amsterdam.

Schein, L. and Oakes, T. (2006) Translocal China: an introduction, in T. Oakes and L. Schein (eds.) Translocal China: Linkages, Identities and the Reimagining of Space. London: Routledge, pp. 1-35.

Scheuer, S. (2011) 'Union membership variation in Europe: prospects and problems: a ten-country comparative analysis', European Journal of Industrial Relations 17(1): 57-73.

Sherman, R. and Voss, K. (2000) Organize or die': labor's new tactics and immigrant workers, in R. Milkman (ed.) Organizing Immigrants: The Challenge for Unions in Contemporary California. Ithaca: Cornell University Press, pp. 81-108.

Sippola, M. (2009) A Low Road to Investment and Labour Management? The Labour Process at Nordic Subsidiaries in the Baltic States. PhD thesis, University of Jyväskyla, Finland.

Sklair, L. (2001) The Transnational Capitalist Class. Oxford: Blackwell Publishers.

Soskice, D. and Hall, P.A. (2001) Varieties of Capitalism: The Institutional Foundations of Comparative Advantage. Oxford: Oxford University Press.

Söderling, I. (2011) Finland, and Migration in the Baltic Sea Region. Baltic Rim Economics, Quarterly Review Issue no. 5, 21. Dec. 2011, pp. 71-72.

Voxted, S. and Lind, J. (2012) 'Too few Indians and too many chiefs. Is this one reason for declining trade union membership in Denmark?', Nordic Journal of Working Life Studies 2(2): $35-49$.

Vranken, J. (1990) Industrial rights, in Z. Leyton Henry (ed.) The Political Rights of Migrant Workers in Western Europe. London: Sage Publications, pp. 47-73.

Watts, J. (2002) Immigration Policy and the Challenge of Globalization. Ithaca/London: Cornell University Press.

Wrede, S. and Nordberg, C. (eds.) (2010) Vieraita työssä. Työelämän etnistyvä eriarvoisuus. [Strangers in Work: The Ethnifying Inequality in Working Life]. Helsinki: Gaudeamus.

Wrench, J. (2004) Breakthroughs and Blind Spots: Trade Union Responses to Immigrants and Ethnic Minorities in Denmark and the UK. Oslo: Fafo.

Zetterberg, S. (2007) Viron Historia. [The History of Estonia]. Helsinki: Tammi. 


\section{Electronic resources}

Baltic Business News Mar 21, 2012 http://www.balticbusinessnews.com/article/2012/3/21/ finland-starts-squeezing-estonian-builders (Jan 7, 2013).

Baltic Times Mar 30, 2012 http://www.baltictimes.com/news/articles/30911/ (Jan 19, 2013).

Working Life Barometer Survey Estonia http://www.eurofound.europa.eu/ewco/surveys/ EE0603SR01/EE0603SR01_10.htm (Jan 3, 2013).

European Social Survey http://www.europeansocialsurvey.org/ (Jan 21, 2013).

Hufvudstadsbladet Jan 19, 2013 http://hbl.fi/nyheter/2013-01-19/estniska-byggjobbare-fickratt-till-finsk-lon (Jan 21, 2013).

Kouvonen, S. (2012) 'Pääkaupunkiseudun palkat ovat toista maata' [The wages differ according to country in the capital region]. Hyvinvointikatsaus 4. http://www.stat.fi/tup/ hyvinvointikatsaus/hyka_2012_04.html (May 15, 2013).

OECD Statextracts http://stats.oecd.org/ (Jan 21, 2013).

Statistics Estonia May 15, 2013 http://www.stat.ee/57482.

Statistics Finland 2011 http://www.stat.fi/tup/suoluk/suoluk_vaesto_en.html\#foreigners (May 15, 2013).

Statistics Finland 2011 http://www.stat.fi/til/pra/2011/pra_2011_2012-10-19_en.pdf (May 15, 2013).

The Estonian Trade Union Confederation proposals for policy formation in 2011-2015 http://www.eakl.ee/failid/58ba1b7b4ae0f475037181e532a0ef37.pdf (Jan 21, 2013).

YLE News (Morning TV) May 31, 2012 http://areena.yle.fi/tv/1571122 (Jan 19, 2013).

YLE News Jun 21, 2012.

http://yle.fi/uutiset/rakennusliitto_patistaa_rakentajia_tarttumaan_veronumeroon/6191819 (Jan 19, 2013).

\section{End notes}

${ }^{1}$ The article also briefly discusses the role of the other national actors in the migration process: employers, migrant workers, and the state, as their strategies affect the possibilities of trade unions (and vice versa).

${ }^{2}$ The previous also applies on a more general level to union strategies toward the entire workforce-not exclusively migrant workers-as unions in antagonistic LME labor markets generally resort more to membership, mobilization, and grassroots initiatives than unions in more coordinated or corporatist institutional settings (Marino 2012; Wrench 2004).

${ }^{3}$ Although trade union renewal strategies focusing on migrant/ethnic minority mobilization have had some success at local and sectoral levels, they have not been able to raise the general trade union density at the national level in the US: between 2000 and 2011 trade union density decreased from 12.9 to $11.3 \%$ (OECD Statextracts).

${ }^{4}$ An example of an exclusive administrative trade union strategy could be efforts for tightening the regulation of work permits for migrants, or actively resisting the liberalization of immigration policy. An example of an inclusive administrative strategy could be a strategy working for the legalization of undocumented migrants. In the Finnish case, trade union administration of unemployment funds is an administrative strategy which has a strong inclusive element, as via legislation it increases incentives for an employee to join a union.

${ }_{5}^{5}$ Data was collected between September 2005 and January 2013. The main type of data consists of key informant interviews with trade union representatives in Estonia and Finland. The focus in the semistructured interviews was on the perceptions and the strategies of the trade unions related to the cross-national mobility of workers and on the general labor 
market/trade union situation in Finland and Estonia. In Finland, the interviewees were selected among representatives of the Finnish Construction Trade Union. The 16 interviewed Construction Union officials consist mainly of persons in leading positions, but also 5 shop stewards were interviewed. The author of this article has conducted all interviews, with the exception of two interviews that were conducted by research assistant Miika Saukkonen. The 18 representatives of Estonian trade unions included the presidents of both central organizations, presidents of their member unions, 5 shop stewards, and the leader of a trade union local in Tallinn. For practical reasons, one of the interviews was conducted with three interviewees and another with two interviewees. Hence, the total number of interviews in Estonia is 14. All interviews in Finland and Estonia were recorded with the exception of one interview with two shop stewards in Estonia. The shop stewards' enterprises and identities are withheld. Some of the interviewees were contacted via e-mail afterward in order to answer additional questions. The Estonian Trade Union Confederation (EAKL) consists of blue collar trade unions, whereas the Estonian Employees' Unions' Confederation (TALO) represents white collar trade unions. The European Social Survey and statistics from Statistics Finland, Statistics Estonia, and OECD were also used as research material. The Estonian interviewees represented the following trade unions:

- EAKL (two interviews, the second interview included a shop steward and leader of a local trade union branch in Tallinn)

- TALO (two interviews)

- EAKL branch in the city of Tartu

- Estonian Communication and Service Workers’ Trade Union

- Estonian Seamen's Independent Union

- Federation of Estonian Metal Workers' Unions

- Estonian Transport and Road Workers' Association (two interviews)

- Estonian Professional Association of Engineers

- Estonian Broadcasting Professionals' Union

- Two shop stewards in a Finnish enterprise

- A shop steward in an Estonian enterprise

- A shop steward in a multinational enterprise

${ }^{6}$ Data supplementing the interviews include public statements of the unions published in their journals, websites, and the Finnish and Estonian media in general. Data were also gathered at seminars and conferences where the representatives of the trade unions presented topics related to the research questions. An example of such an occasion is the Finnish Social Forum in Helsinki (years 2009-2011). I also interviewed Professor Allan Puur from Tallinn University and Professor of macroeconomics Raul Eamets from the University of Tarto as academic experts on the Estonian labor market structure and demographic challenges.

${ }^{7}$ However, an unknown share of the Estonian workers is self-employed and hence not potential trade union members. Alho (2008) has calculated that in 2006 the Finnish trade unions had 15,220 migrant members, and the density of migrants belonging to trade unions was $26 \%$, which is far below the national average of almost $70 \%$. The number of migrant members in Finnish trade unions has, however, increased and totaled, according to trade union estimates, between 26,000 and 27,000 in 2011 (Kyntäjä 2011). Hence, between 2006 and 2011, the increase of migrant members was between 71 and $77 \%$ (during the same time period the immigrant population increased by $43 \%$ in Finland).

In other words, in an era when the share of workers belonging to a trade union has decreased, migrants are increasingly joining unions. Nevertheless, migrants are still underrepresented in leading positions, representative bodies, and as employees in Finnish trade unions, including the FCTU (Alho 2010; Ristikari 2013). 